\title{
The hypoglycemic effect of plant derived insulin like protein in comparison to the hypoglycemic effect of the human soluble insulin in diabetic mice
}

\author{
Hassan R.J ${ }^{1}$, Hadi N.A ${ }^{1}$, And Shayma`A Jamal Ahmed. ${ }^{2 *}$ \\ Pharmacology, College of Medicine, Baghdad University, Baghdad, Iraq \\ Anatomy Department, College of Medicine, Baghdad University, Baghdad, Iraq
}

\begin{abstract}
Diabetes is one of the most challenging health problems in 21 century and insulin is the only effective treatment for type 1 diabetes mellitus and also an alternative treatment for type 2 diabetes mellitus in some conditions, and since the cost of insulin increased dramatically since 1990s, herbs and medicinal plants with a hypoglycemic effect become more popular especially in developing countries as a lower cost alternatives, Bauhinia varigta leaves alcoholic extract hypoglycemic activity were evaluated and compared to that of soluble insulin in alloxanized diabetic mice. HPLC analysis was applied to identify the presence of protiens similar to soluble insulin, also biological effects of the extract on sperm head morphology was evaluated. Bauhinia varigata alcoholic extract show a good hypoglycemic activity in compare to soluble insulin in diabetic mice, with possible presence of peptide similar to insulin, also it has a good effect in reducing risk of sperm head abnormalities.
\end{abstract}

\section{Introduction}

Diabetes mellitus (DM) is a metabolic disorder resulting from a defect in insulin secretion, insulin action, or both. Insulin deficiency in turn leads to chronic hyperglycemia with disturbances of carbohydrate, fat and protein metabolism. It is the most common endocrine disorder and by the year 2025, 300 million of people worldwide will have the disease (1), Insulin remains the only anti hyperglycemic therapy for type 1 diabetes, while oral agents have been the main therapy for type 2 diabetes. But they are limited in their ability to maintain tight glycemic control in the long term. Therefore, earlier initiation of insulin in patients with type 2 diabetes ensure tight glycemic control through the period of progressive Beta cell failure and secondary failure of oral antidiabetic agents(2).also insulin is the first choice treatment in gestational diabetes(3). in Eastern Europe, Asia, South America and other resource -limited countries, insulin is expensive and relatively un affordable, especially with new insulin preparation like insulin pen that provide good patient compliance especially for young population(4) therefore a lot of populations in these countries and in other poor countries depend on herbal medicine to treat their diabetes and in the last few years, these drugs gained popularity both in developing and developed countries. There are more than 1000 plants which are used in antidiabetic herbal formulations and among them about 100 plants have been scientifically validated (5).

Bauhinia variegata is a species of flowering plant in the family Caesalpiniaseae, (6). The leaves of different Bauhinia species are used in antidiabetic treatments by many populations of the world. (7). ethanolic extract of Bauhinia varigata anti diabetic effect was evaluated in alloxan induced diabetic rats, and the results shows a significant reduction of blood glucose level (8).

\section{Plant Materials:}

\section{Materials and methods:}

Bauhinia variegata: the parts of plant used in the experiment are the leaves which were collected from University of Baghdad gardens, Al-Jaderya. (mid-September).

\section{Preparation of leaves extract:}

Dried leaves of Bauhinia variegata is grinded by mortar to fine powder, and then ethanolic or alcoholic extraction was done. 50gof powder to $250 \mathrm{ml}$ of $70 \%$ ethanol (1:5) and allow to stand at room temperature for 3 days, homogenized by frequent shaking, then filtered with 4 layers sterile gauze and by Wattman no.1 flitter paper respectively, to get pure extract of both plants.(9)

\section{Laboratory animals:}

In this study, adult albino mice weighting between $30-35 \mathrm{~g}$ were used. These animals were provided by the (Animal Breeding Center at college of medicine, university of Baghdad) and from (the National Center for 
control and pharmaceutical researches). Animals were distributed in cages at room temperature $20-25^{\circ} \mathrm{C}$ under $12 \mathrm{~h} \mathrm{light/dark} \mathrm{cycle} \mathrm{and} \mathrm{allowed} \mathrm{free} \mathrm{access} \mathrm{to} \mathrm{water} \mathrm{and} \mathrm{commercial} \mathrm{food} \mathrm{pellet.}$

\section{High Performance Liquid Chromatography analysis HPLC:}

HPLC Analysis for alcoholic extract of Bauhinia variegata had been carried out by analytical department in Ibn Sina State Company, a subsidiary of the Ministry of Industry and Minerals. Soluble insulin was used as an external standard for the analyte. By comparing the chromatogram of the sample against that of a reference standard, both qualitative and quantitative analyses can be applied, qualitative analysis by measuring the retention time of each component peak that is, the time required for an analyte to be eluted from the column versus the retention times in a standard (10).Chromatographic conditions :Flow $=1 \mathrm{ml} / \mathrm{min}$, Wavelength=280 $\mathrm{nm}$, Mobile phase $=95 \%$ acetonitrile $+5 \% \mathrm{H} 2 \mathrm{O}$, Injector volume $=10 \mu 1$, Colum $=\mathrm{C} 18250 * 4.60 \mathrm{~mm} 5$ macron Type of the instrument or HPLC system is Shamadzu LC2010 ATH.

\section{Acute toxicity measurement:}

Acute toxicity studies for ethanolic extracts of Bauhinia variegata leaves were done by exposing the experimental animals (in typical group sizes of two to five animals/group) to various doses of the test compound, i.e. from the maximal non-lethal dose determined in the acute studies down to doses in the pharmacological dose range.(11)The animals were observed for any changes continuously for the first 24h and up to $48 \mathrm{~h}$ for mortality.different doses administered intraperitonially to groups of mice and as shown in table( $1)$.

Table (1) concentrations of Bauhinia variegata leaves alcoholic extract in $\mathrm{mg} / \mathrm{kg}$ that was administered to groups of mice gradually

\begin{tabular}{|l|l|}
\hline $\begin{array}{l}\text { No of mice } \\
\text { in group }\end{array}$ & Concentration in $\mathrm{mg} / \mathrm{kg}$ \\
\hline 5 & $25 \mathrm{mg} / \mathrm{kg}$ \\
\hline 5 & $50 \mathrm{mg} / \mathrm{kg}$ \\
\hline 5 & $100 \mathrm{mg} / \mathrm{kg}$ \\
\hline 5 & $200 \mathrm{mg} / \mathrm{kg}$ \\
\hline 5 & $2000 \mathrm{mg} / \mathrm{kg}$ \\
\hline 5 & $2500 \mathrm{mg} / \mathrm{kg}$ \\
\hline 5 & $3000 \mathrm{mg} / \mathrm{kg}$ \\
\hline 5 & $3500 \mathrm{mg} / \mathrm{kg}$ \\
\hline 5 & $4000 \mathrm{mg} / \mathrm{kg}$ ( crude) \\
\hline
\end{tabular}

\section{Diabetes mellitus type 1 induction and measurement ofBlood glucose level:}

Alloxan crystals were weighted then dissolved in cold normal saline $0.09 \%$ and administere to mice in a dose of $150-\mathrm{mg} / \mathrm{kg}$ body weight every 48 hour. Total alloxan received at last was $450 \mathrm{mg} / \mathrm{kg}$. One week after the third injection, the mice were fasted again and fasting blood glucose levels were recorded.(12). fasting blood glucose was measured by using a glucometer type (accucheck performa). Mice with fasting blood glucose level $\geq 150 \mathrm{mg} / \mathrm{dl}$ were considered diabetic and included in the study (13).

\section{Administration of the ethanolic extract of Bauhinia varigata leaves:}

40 mice (30 diabetic +10 healthy non diabetic) were divided in 4 groups $(10$ mice in each group. Group M1: healthy mice received 10 units of normal saline $0.9 \%$ once daily at 9AM (Rashid et al., 2013),Group M2: diabetic mice received 10 unit of normal saline $0.9 \%$ once daily at 9AM,GroupM3: diabetic mice received 10 unit of soluble insulin 3 times daily 9 AM, 4PM, 8PM. (Insulin dose for mice is $1 \mathrm{IU} / \mathrm{kg}$ body weight). (14)Group M4: diabetic mice received 10 unit of Bauhinia variegata once daily at9AM. Treatment course was 14 days (14), and fasting blood glucose level was measured on daily bases at $8 \mathrm{AM}$ after $6 \mathrm{~h}$ fasting (15)

\section{Sperm abnormalities assessment:}

Animals were sacrificed after 7 days, 14 days and 21 days according to Banerjee method through cervical dislocation,the examination was done according to Wyrobek and Bruce(16).

\section{HPLC analysis}

\section{Results:}

HPLC analysis results was represented by chromatograms with tables illustrated no. of peaks, retention time, height percent and area percent. 


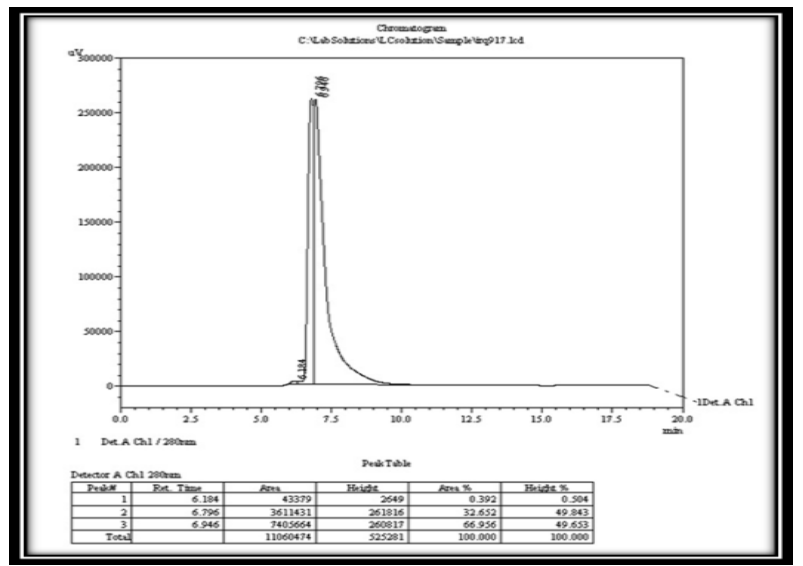

Figure (1) HPLC chromatogram for soluble insulin (standard solution)

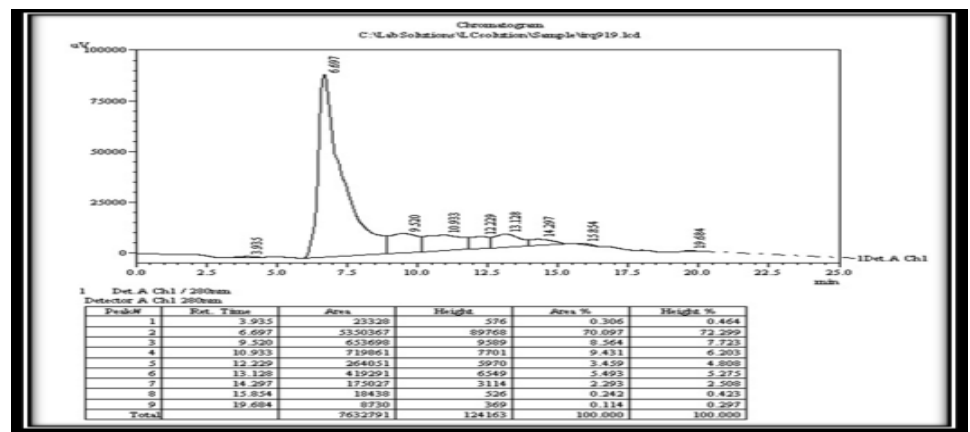

Figure (2) HPLC chromatogram for alcoholic extract of Bauhinia variegata leaves

\section{Acute toxicity and determination of lethal dose LD50 in mice:}

Bauhinia variegate alcoholic extract acute toxicity test results showed that no dead animals or toxicity signs appeared in mice groups after 24 and $48 \mathrm{~h}$ and at concentrations up to $4000 \mathrm{mg} / \mathrm{kg}$, and accordingly LD50 for Bauhinia variegate is estimated to be higher than $4000 \mathrm{mg} / \mathrm{kg}$ (which is the crude extract) and the therapeutic doses administered for evaluating hypoglycemic activity was $200 \mathrm{mg} / \mathrm{kg}(1),(17)$.

Table (2) Number of dead mice in each group after $24 \mathrm{~h}$ and $48 \mathrm{~h}$ from administration of different concentration of Bauhinia variegata leaves alcoholic extract.

\begin{tabular}{|l|l|l|l|}
\hline $\begin{array}{l}\text { Concentration in mg/kg body } \\
\text { weight }\end{array}$ & No of mice in each group & No of dead mice after 24h & No of dead mice after 48h \\
\hline $25 \mathrm{mg} / \mathrm{kg}$ & 5 & 0 & 0 \\
\hline $50 \mathrm{mg} / \mathrm{kg}$ & 5 & 0 & 0 \\
\hline $100 \mathrm{mg} / \mathrm{kg}$ & 5 & 0 & 0 \\
\hline $200 \mathrm{mg} / \mathrm{kg}$ & 5 & 0 & 0 \\
\hline $2000 \mathrm{mg} / \mathrm{kg}$ & 5 & 0 & 0 \\
\hline $2500 \mathrm{mg} / \mathrm{kg}$ & 5 & 0 & 0 \\
\hline $3000 \mathrm{mg} / \mathrm{kg}$ & 5 & 0 & 0 \\
\hline $3500 \mathrm{mg} / \mathrm{kg}$ & 5 & 0 & 0 \\
\hline
\end{tabular}

3. Measurement of fasting blood glucose level after administration of plant extract to mice groups:

Fasting blood glucose level for mice in each of the four groups was measured on daily basis at morning for 15 days. . Table (3) shows the Mean M and Standard deviation SD for these measurements of each group for 15 days

Table (3) the Mean M and Standard deviation SD for these measurements of each group for 15days

\begin{tabular}{|l|l|l|l|l|l|}
\hline Day & Groups & Mean \pm SD & Day & groups & Mean \pm SD \\
\hline 0 & M1 & $83.7 \pm 9.63$ & 8 & M1 & $78.1 \pm 10.24$ \\
& M2 & $176.8 \pm 27.24$ & & M2 & $185.6 \pm 37.94$ \\
& M3 & $173.5 \pm 17.79$ & & M3 & $108.1 \pm 16.45$ \\
& M4 & $178.4 \pm 21.44$ & & M4 & $125.5 \pm 14.52$ \\
\hline 1 & M1 & $85.9 \pm 12.65$ & 9 & M1 & \\
& M2 & $174 \pm 18.98$ & & M2 & $17.2 \pm 10.89$ \\
& M3 & $103 \pm 18.72$ & & M3 & $107.6 \pm 19.11$ \\
\hline
\end{tabular}


The hypoglycemic effect of plant derived insulin like protein in comparison to the hypoglycemic effect

\begin{tabular}{|c|c|c|c|c|c|}
\hline & M4 & $139.9 \pm 18.06$ & & M4 & $124.1 \pm 19.56$ \\
\hline 2 & $\begin{array}{l}\text { M1 } \\
\text { M2 } \\
\text { M3 } \\
\text { M4 }\end{array}$ & $\begin{array}{l}85 \pm 13.055 \\
169.1 \pm 17.72 \\
110 \pm 14.59 \\
128 \pm 18.68\end{array}$ & 10 & $\begin{array}{l}\text { M1 } \\
\text { M2 } \\
\text { M3 } \\
\text { M4 }\end{array}$ & $\begin{array}{l}82 \pm 11.62 \\
174.7 \pm 19.87 \\
105 \pm 14.61 \\
111.6 \pm 20.04\end{array}$ \\
\hline 3 & $\begin{array}{l}\text { M1 } \\
\text { M2 } \\
\text { M3 } \\
\text { M4 }\end{array}$ & $\begin{array}{l}86.2 \pm 11.91 \\
181.5 \pm 18.91 \\
109.2 \pm 12.89 \\
131.8 \pm 23.51\end{array}$ & 11 & $\begin{array}{l}\text { M1 } \\
\text { M2 } \\
\text { M3 } \\
\text { M4 }\end{array}$ & $\begin{array}{l}82.3 \pm 13.72 \\
167.1 \pm 16.77 \\
105.6 \pm 13.82 \\
123.8 \pm 19.86\end{array}$ \\
\hline 4 & $\begin{array}{l}\text { M1 } \\
\text { M2 } \\
\text { M3 } \\
\text { M4 }\end{array}$ & $\begin{array}{l}90 \pm 10.20 \\
173 \pm 17.65 \\
107 \pm 12.21 \\
130.3 \pm 15.76\end{array}$ & 12 & $\begin{array}{l}\text { M1 } \\
\text { M2 } \\
\text { M3 } \\
\text { M4 }\end{array}$ & $\begin{array}{l}83.5 \pm 12.75 \\
166.2 \pm 17.46 \\
100.8 \pm 18.67 \\
120.3 \pm 20.13\end{array}$ \\
\hline 5 & $\begin{array}{l}\text { M1 } \\
\text { M2 } \\
\text { M3 } \\
\text { M4 }\end{array}$ & $\begin{array}{l}86.5 \pm 14 \\
173.6 \pm 19.26 \\
102.1 \pm 14 \\
132.7 \pm 21.18\end{array}$ & 13 & $\begin{array}{l}\text { M1 } \\
\text { M2 } \\
\text { M3 } \\
\text { M4 }\end{array}$ & $\begin{array}{l}81 \pm 11.33 \\
170.8 \pm 15.83 \\
106.3 \pm 13.61 \\
126.1 \pm 14.28\end{array}$ \\
\hline 6 & $\begin{array}{l}\text { M1 } \\
\text { M2 } \\
\text { M3 } \\
\text { M4 }\end{array}$ & $\begin{array}{l}81.6 \pm 12.72 \\
178.6 \pm 17.58 \\
101.3 \pm 14.47 \\
115.3 \pm 19.98\end{array}$ & 14 & $\begin{array}{l}\text { M1 } \\
\text { M2 } \\
\text { M3 } \\
\text { M4 }\end{array}$ & $\begin{array}{l}11.800 \pm 79.5 \\
14.72 \pm 175.5 \\
13.63 \pm 96.5 \\
17.94 \pm 117.1\end{array}$ \\
\hline
\end{tabular}

Table (3) Correlation between mean fasting blood glucose levels of all groups and days

\begin{tabular}{|c|c|c|c|c|c|c|c|c|c|}
\hline \multirow{2}{*}{\multicolumn{2}{|c|}{ Day }} & \multicolumn{8}{|l|}{ Groups } \\
\hline & & \multicolumn{2}{|l|}{ M1 } & \multicolumn{2}{|l|}{ M2 } & \multicolumn{2}{|l|}{ M3 } & \multicolumn{2}{|l|}{ M4 } \\
\hline$\overline{\mathbf{i}}$ & $\overline{\mathbf{j}}$ & $\begin{array}{l}\text { Mean } \\
\text { difference(i-j) }\end{array}$ & P value & $\begin{array}{l}\text { Mean } \\
\text { difference }\end{array}$ & P value & Mean difference & P value & $\begin{array}{l}\text { Mean } \\
\text { difference }\end{array}$ & P value \\
\hline $\mathbf{0}$ & $\begin{array}{l}1 \\
2 \\
3 \\
4 \\
5 \\
6 \\
7 \\
8 \\
9 \\
10 \\
11 \\
12 \\
13 \\
14\end{array}$ & $\begin{array}{l}-2.2 \\
-1.3 \\
-2.5 \\
-6.3 \\
-2.8 \\
2.1 \\
-2.3 \\
5.6 \\
4.5 \\
1.7 \\
1.4 \\
0.2 \\
2.7 \\
4.2\end{array}$ & $\begin{array}{l}\text { Not sig. } \\
\text { Not sig } \\
\text { Not sig. } \\
\text { Not sig. } \\
\text { Not sig. } \\
\text { Not sig. } \\
\text { Not sig. } \\
\text { Not sig. } \\
\text { Not sig. } \\
\text { Not sig. } \\
\text { Not sig. } \\
\text { Not sig. } \\
\text { Not sig. } \\
\text { Not sig. }\end{array}$ & $\begin{array}{l}2.8 \\
5.7 \\
-4.7 \\
3.8 \\
3.2 \\
-1.8 \\
2.9 \\
-8.8 \\
2.2 \\
2.1 \\
9.7 \\
10.6 \\
6 \\
1.3\end{array}$ & $\begin{array}{l}\text { Not sig. } \\
\text { Not sig. } \\
\text { Not sig. } \\
\text { Not sig. } \\
\text { Not sig. } \\
\text { Not sig. } \\
\text { Not sig. } \\
\text { Not sig. } \\
\text { Not sig. } \\
\text { Not sig. } \\
\text { Not sig. } \\
\text { Not sig. } \\
\text { Not sig. } \\
\text { Not sig. }\end{array}$ & $\begin{array}{l}69.60 \\
63.50 \\
64.30 \\
66.10 \\
71.40 \\
72.20 \\
70.50 \\
65.37 \\
66.00 \\
68.50 \\
67.87 \\
72.62 \\
67.12 \\
77.00\end{array}$ & $\begin{array}{l}\text { sig. } \\
\text { sig. } \\
\text { sig. } \\
\text { sig. } \\
\text { sig. } \\
\text { sig. } \\
\text { sig. } \\
\text { sig. } \\
\text { sig. } \\
\text { sig. } \\
\text { sig. } \\
\text { sig } \\
\text { sig. } \\
\text { sig. }\end{array}$ & $\begin{array}{l}38.50 \\
49.80 \\
46.60 \\
48.10 \\
45.70 \\
63.10 \\
60.20 \\
52.90 \\
54.27 \\
66.77 \\
54.52 \\
58.02 \\
52.27 \\
61.27\end{array}$ & $\begin{array}{l}\text { Sig. } \\
\text { Sig. } \\
\text { Sig. } \\
\text { Sig. } \\
\text { Sig. } \\
\text { Sig. } \\
\text { Sig. } \\
\text { Sig. } \\
\text { Sig. } \\
\text { Sig. } \\
\text { Sig. } \\
\text { Sig. } \\
\text { Sig. } \\
\text { Sig. }\end{array}$ \\
\hline
\end{tabular}

$P$ value $<.005=$ sig. $p$ value $>.005$ not sig., day $0=$ day before starting the treatment

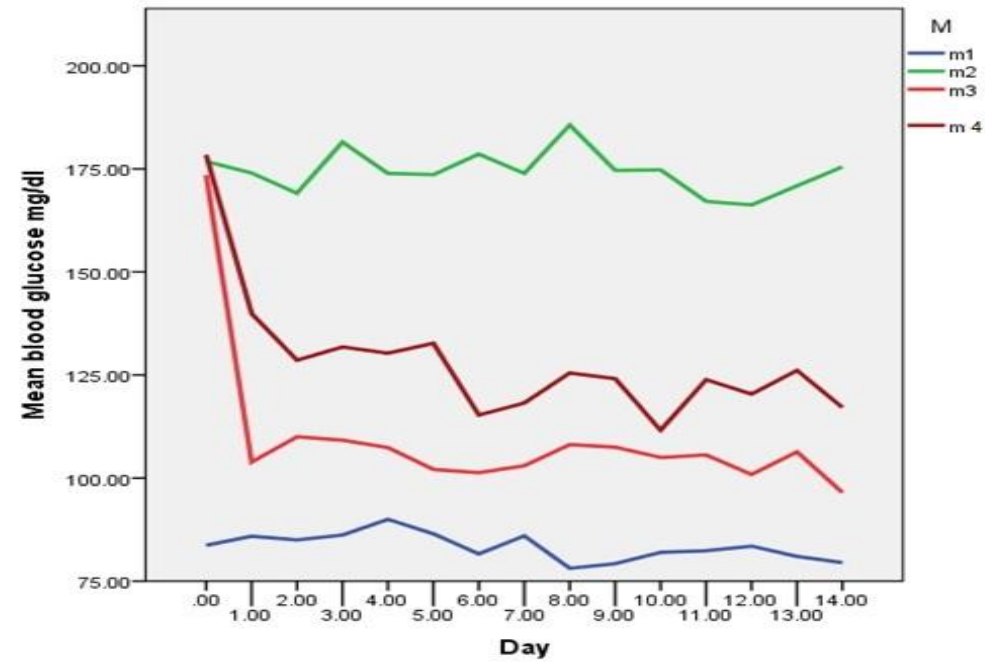

Figure (3) mean blood glucose levels for group M2, M3, M4, M5, M6 in mg/dl treatment in14 days 


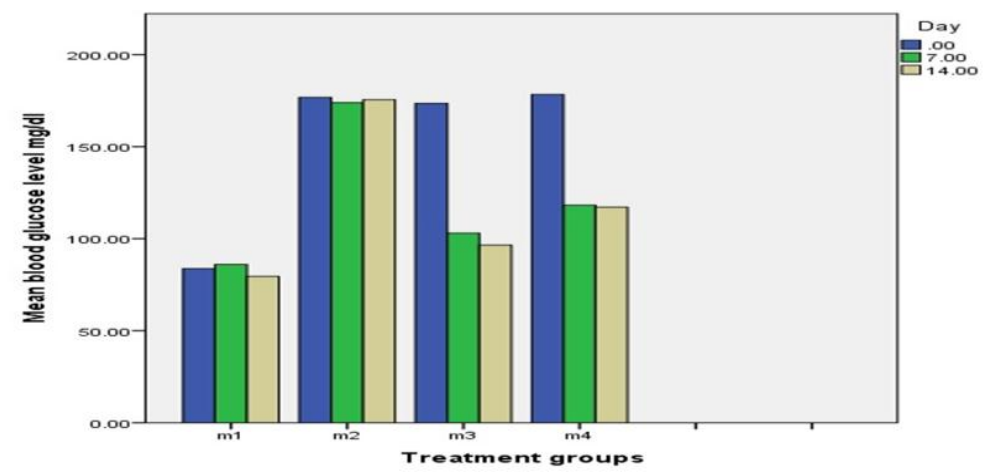

Figure (4) Mean blood glucose levels for all groups at day 0, 7, 14 Of treatment

\section{Sperm head abnormalities:}

Sperm head abnormalities detected under microscope including: no head, balloon head, thread head and curved head with no hook, day 7, 14, and 21 from start of treatment.th e abnormal morphology of sperm is show in figure (5a), (5b), (5c), (5d)and (5e).

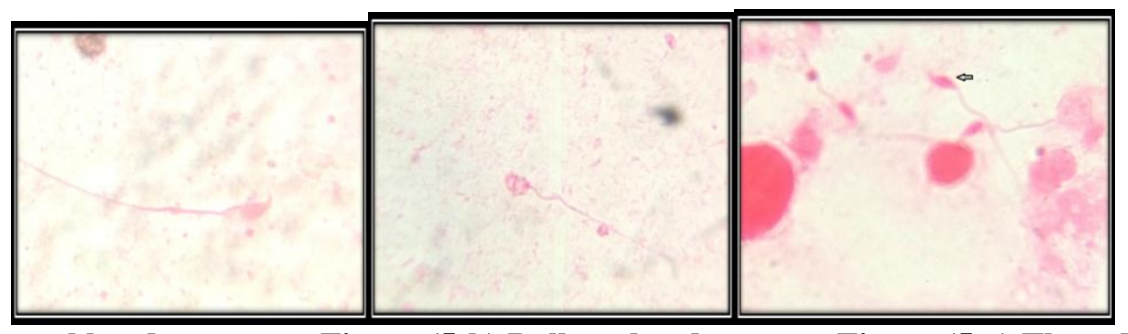

Figure (5-a) Normal head sperm $\quad$ Figure (5-b) Balloon head sperm Figure (5-c) Thread head sperm

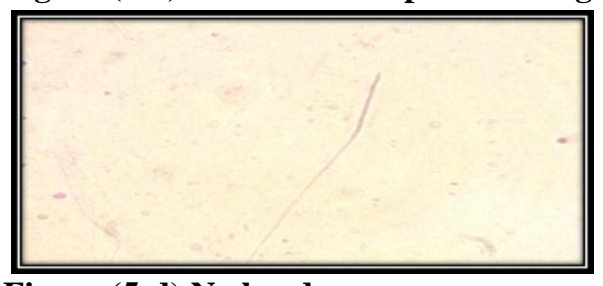

Figure (5-d) No head sperm

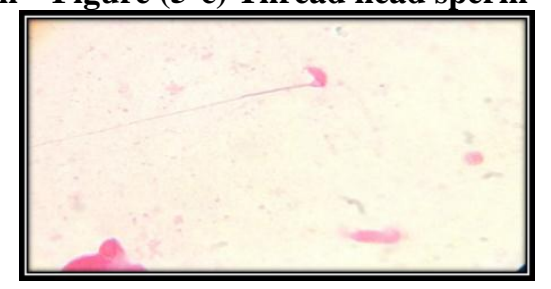

Figure(14-e)Curved no hook sperm

Table (4) the relationship between sperm head abnormalities in each groups at days 7, 14, 21

\begin{tabular}{|c|c|c|c|c|c|c|c|c|c|c|c|c|c|c|c|}
\hline \multirow{3}{*}{ Group } & \multicolumn{15}{|c|}{ Types of sperm head abnormalities } \\
\hline & \multicolumn{3}{|c|}{ Normal\% } & \multicolumn{3}{|c|}{ Balloon head\% } & \multicolumn{3}{|c|}{ Thread head\% } & \multicolumn{3}{|c|}{ No head\% } & \multicolumn{3}{|c|}{ Curved head no hook\% } \\
\hline & $\begin{array}{l}\text { Day } \\
7\end{array}$ & $\begin{array}{l}\text { Day } \\
14\end{array}$ & $\begin{array}{l}\text { Day } \\
21\end{array}$ & $\begin{array}{l}\text { Day } \\
7\end{array}$ & $\begin{array}{l}\text { Day } \\
14\end{array}$ & day 21 & $\begin{array}{l}\text { Day } \\
7\end{array}$ & Day14 & Day21 & $\begin{array}{l}\text { Day } \\
7\end{array}$ & $\begin{array}{l}\text { Day } \\
14\end{array}$ & $\begin{array}{l}\text { Day } \\
21\end{array}$ & Day7 & Day14 & Day21 \\
\hline M1 & 100 & 100 & 100 & 0 & 0 & 0 & 0 & 0 & 0 & 0 & 0 & 0 & 0 & 0 & 0 \\
\hline M2 & 55 & 36 & 37 & 24 & 46 & 47 & 6 & 9 & 11 & 7 & 3 & 6 & 8 & 4 & 1 \\
\hline M3 & 74 & 51 & 68 & 29 & 32 & 22 & 4 & 4 & 8 & 8 & 5 & 2 & 5 & 6 & 0 \\
\hline M4 & 55 & 49 & 70 & 25 & 38 & 7 & 4 & 14 & 4 & 4 & 5 & 5 & 10 & 4 & 4 \\
\hline $\begin{array}{l}\text { p- } \\
\text { value }\end{array}$ & Sig. & Sig. & Sig. & Sig. & Sig. & Sig. & $\begin{array}{l}\text { Not } \\
\text { sig. }\end{array}$ & Sig. & $\begin{array}{l}\text { Not } \\
\text { sig }\end{array}$ & $\begin{array}{l}\text { Not } \\
\text { sig. }\end{array}$ & $\begin{array}{l}\text { Not } \\
\text { sig. }\end{array}$ & $\begin{array}{l}\text { Not } \\
\text { sig. }\end{array}$ & Sig. & $\begin{array}{l}\text { Not } \\
\text { sig. }\end{array}$ & $\begin{array}{l}\text { Not } \\
\text { sig. }\end{array}$ \\
\hline
\end{tabular}

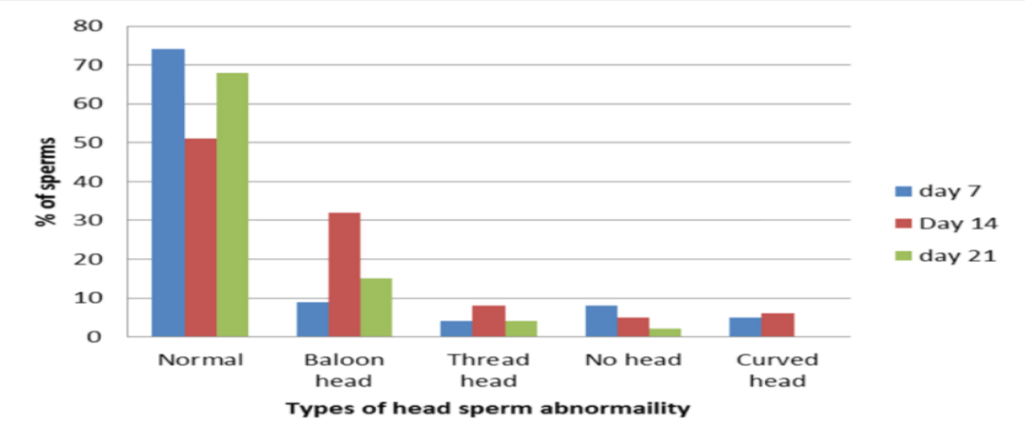

Figure (6) Relation between head sperm abnormalities for group M3 that receive soluble insulin at day 7, 14, 21 of the treatment 


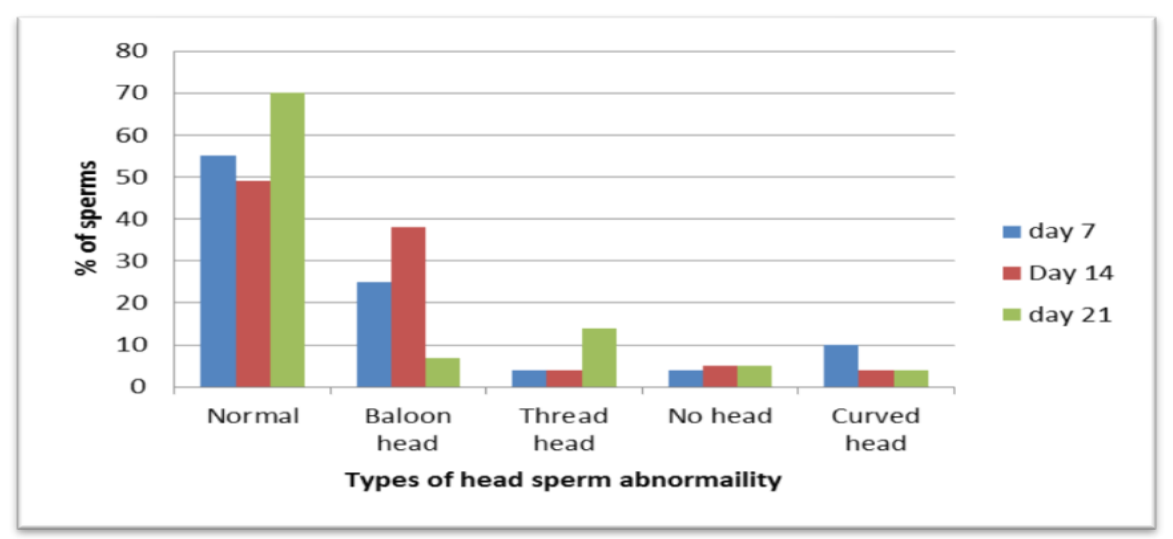

Figure (7) the relation between abnormal head sperms for group M5 that receive Bauhinia varigata leaves alcoholic extract at day $7,14,21$ of the treatment.

\section{Discussion:}

In HPLC, the separation of a mixture of peptides and proteins arises from the differential absorption of each solute according to their affinity for the immobilized stationary phase(18), alcoholic extract of Bauhinia variegata was analysed qualitatively Using soluble insulin solution as an external standard for the analyte, this was done by measuring the retention time of each component peak that is, the time required for an analyte to be eluted from the column versus the retention times in a standard solution, the chromatogram of soluble insulin show the presence of 3 peaks with retention time values (6.184), (6.796), and (6.946), the chromatogram of Buhinia varigata alcoholic extract shows 9 peaks, one peak with retention time (6.69). Bauhenina varigata alcoholic extracts have compounds with a retention times very close to that of soluble insulin, which means that both plant alcoholic extract have compound with chemical structure similarities to that of soluble insulin, excluding any factors affecting the retention time since all the compound were analyzed under the same chromatographic condition. ).this is in agreement with (19) which indicated that HPLC chromatographic analysis of Bauhinia varigata show insulin like properties. for Bauhenina varigata alcoholic extract, no deaths or toxicity signs and symptoms observed after $24 \mathrm{~h}$ and $48 \mathrm{~h}$ in all concentration that was administered and therefore the LD50 is considered higher than $4000 \mathrm{mg} / \mathrm{kg}$ (which is the crude or highest extract concentration) and according to (Loomis and Hayes, 1996) its considered slightly toxic. Number of studies reported the LD50 of Buahinia varigata leaves extract after intraperitonial administration experimental animals, (1) and (20) suggested that Bauhenina varigata is safe up to the dose $2000 \mathrm{mg} / \mathrm{kg}$ when administered orally to albino mice, while(21)showed that LD50 for terpens that derived from Bauahenia varigata is $3000 \mathrm{mg} / \mathrm{kg}$ when administered orally to albino mice. Table (3) showed that the correlation between blood glucose levels for group M1 and M2 and days in compare to the day before starting the treatment is not significant while it's significant for group M3, M4, this is because M1 and M2 didn't receive any treatment during the course of treatment only normal saline $0.09 \%$ which has no effect on the blood glucose level, So no changes occurred in the blood glucose level readings. While other groups receive insulin and alcoholic extract of Bauhenia varigata leaves for 14 days which lead to alteration in the blood glucose level readings during the course of treatment. the mean blood glucose level for groupM3 drop by $40.6 \%$ after 7 days of the treatment and by $60 \%$ after 14 days of the treatment, for, for group M4 the drop in mean blood glucose level after 7 days was $33.7 \%$ and $34.3 \%$ after 14 days, Bauhinia varigata leaves alcoholic extract has a significant hypoglycemic activity when given at dose $(200 \mathrm{mg} / \mathrm{kg})$ once daily for 14 days, this indicates that this plant may have peptides similar to insulin in structure or action since the effect is unlikely caused by other mechanisms and if present will not be able alone to produce this effect in mice with type 1 diabetes, because type 1 diabetes induced by alloxan in mice associated with extensive Beta cells damage and subsequent reduction in insulin release, also sulphonyl urea that act on stimulating insulin release showed a small or week hypoglycemic effect in alloxan induced diabetic mice, Therefore a test plant extract producing a significant hypoglycemia (in alloxan induced diabetic animals) must have different mechanisms to give this effect.(22). Sperm head abnormalities were observed in diabetic mice after 7 days, 14 days and 21 days of the treatment and in all 4 groups.

Table (4) shows the relationship between sperm head abnormalities in all groups after 7, 14 and 21day of the treatment, After 7 days of the treatment, the difference between the 4 groups and head sperm abnormalities insignificant for normal and balloon head sperms while its insignificant for the rest types of abnormalities, , After 14 days of the treatment the difference between the 4 groups is significant for normal, balloon head and thread head sperms while its insignificant for the no head and curved head no hook sperms. After 21 days of the treatment the difference between the 4 groups is significant for normal, balloon and insignificant for the rest types of abnormalities. 
This means that diabetes affect spermatogenesis and result in many types of morphological abnormalities mainly balloon head sperms, and this agree with many studies in this field (23), balloon head sperm orglobozoospermia is a morphological disorder that consists of round-headed, acrosomeless spermatozoa and lead to infertility.( 24), and studies showed that its associated with high level of DNA fragmentation chromosomal abnormalities(25).Soluble insulin and Bauhinia varigata leaves alcoholic extractcould reverse or reduce this effect and this agree with( 26) who suggest that morphological and functional spermatozoal abnormalities that have been detected in diabetic animal models appear to be reversible with insulin administration and insulin could prevent spermatogenic abnormalities .

For plant extract, the effect is either due to direct interaction with insulin targets like sperm membrane and acrosome and this agree with (27)or due to indirect effect by reversing hyperglycemia and as a result decrease ROS that's associated with high risk of head sperm morphological abnormalities and this agree with(28). Also figures (6) and (7) results also clarified that percent abnormal sperms was not affected after 7 days but there was decrease in the head sperm abnormalities after 21 days of treatments this may be attributed to that In the mouse, the spermatogenic cycle length is 8.6 days(29), which means that the effect of the treatment on sperms will not be obvious after 7 days or even 14 days of the treatment, but may be noticeable after 21 days of the treatment.

\section{References:}

[1]. Bastaki S., Review Diabetes mellitus and its treatment, Int J Diabetes \& Metabolism, 13:111-134, 2005.

[2]. Barnett A.H., Insulin Glargine in the Treatment of Type 1 and Type 2 Diabetes, Vasc Health Risk Manag. 2(1): 59-67, 2006.

[3]. Novak B., Renar I.P., Metelko Z., Treatment of diabetes during pregnancy. Diabetologia Croatica 33(1), 2004.

[4]. Gill G.V., Yudkin J. S., Keen H., and Beran D., The insulin dilemma in resource-limited countries .A way forward?Diabetologia, (54) :1,pp 19-24, 2011.

[5]. Chawla R., ThakurP., Chowdhrya A., Jaiswal S., Sharma A., Goel R., SharmaJ., PriyadarshiS.S., KumarV., SharmaR.K. and Arora R.Evidence based herbal drug standardization approach in coping with challenges of holistic management of diabetes: a dreadful lifestyle disorder of 21st centuryJournal of Diabetes \& Metabolic Disorders, 12:35, 2013.

[6]. Devi C.A., Docking study on Mycobacterium tuberculosis receptors AccD5 and PKS18 with selected phytochemical, Journal of Pharmacy and Biological Sciences, Volume 4, Issue 3 PP 01-04., 2012.

[7]. Kumar P., Baraiya S., Gaidhani S.N., Gupta M.D, and Wanjari M.M., Antidiabetic activity of stem bark of Bauhinia variegata in alloxan-induced hyperglycemic rats, J Pharmacol Pharmacother ., v.3(1)., 2012.

[8]. Koti B.C., Biradar S.M., Karadi R.V., Tarnalli A.D., Benade V.S., Effect of Bauhinia variegata bark extract on blood glucose level in normal and Alloxanized diabetic rats. Vol 9/127-34, 2009.

[9]. Handa S.S., Khanuja S.P.S., Longo G., Rakesh D.D., Extraction Technologies for Medicinal and Aromatic Plants, International Centrefor Science and High Technology, 2008.

[10]. Weston A., BrownP.R., High Performance Liquid Chromatography \& Capillary Electrophoresis: Principles and Practices, Academic Press, Science - 280 pages, 1997.

[11]. Mukinda J.T., Acute and chronic toxicity of the flavonoid- containing plant, Artemisia afra in rodents, 2005.

[12]. Fagbohun T.R., Odufuwa K.T., Hypoglycemic effect of methanolic extract of Anacardium occidentale leaves in alloxan-induced diabetic rats, Niger J Physiol Sci. 25;25(1):87-90, 2010.

[13]. Stanley M. P., Venugopal M.P., Anti-oxidant action of Tinospora cordifolia root extract in alloxan diabetic rats. Phytother Res.15: 213-21, 2001.

[14]. Maiti, R., Jana, D., Das, U.K., Ghosh, D. Antidiabetic effect of aqueous extract of seed of Tamarindus indica in streptozotocininduced diabetic rats. J. Ethnopharmacol., Lausanne, v.92, p.85-91, 2004.

[15]. Ayala J.E., Samuel V.T., Morton G.J., Obici S., Croniger C.M., Shulman G.I., Wasserman D.H., McGuinness O.P., Standard operating procedures for describing and performing metabolic tests of glucose homeostasis in mice. Dis Model Mech 3: 525-534, 2010 .

[16]. Wyrobek A.J. and Bruce W.R., Chemical induction of sperm abnormalities in miceProc Natl Acad Sci U S A.72 (11): $4425-4429$, 1975.

[17]. Begali R.S., M Pharm, Screening of Anti-Oxidant, AntiDiabetic, and Hepatoprotectice activity of selected medicinal plants, 2011.

[18]. Aguilar M.I., HPLC of Peptides and Proteins: Basic Theory and Methodology; Page Range: 3-8, 2003.

[19]. Azevedo C.R., Maciel F.M., Silva L.B., Ferreira A.T, da Cunha M., Machado O.L., Fernandes K.V., Oliveira A.E., Filho J.X., Isolation and intracellular localization of insulin-like proteins from leaves of Bauhinia variegata, Braz J Med Biol Res.;39(11):143544, 2006

[20]. Saha S., Subrahmanyam E.V.S., Chandrashekar K.S. and Shastry S.C., In Vivo Study for Anti-inflammatory Activity of Bauhinia variegata L. Leaves, Pharmaceutical Crops, 2, 70-7, 2011.

[21]. Mohamed M.A., Mammoud M.R.and Hayen H., Evaluation of Antinociceptive and Anti-Infl ammatory Activities of a New Triterpene Saponin from Bauhinia variegata Leaves, Z. Naturforsch. 64 c, 798 - 808, 2009.

[22]. Etuk E., Animals models for studying diabetes mellitus, Agric. Biol. J. N. Am., 1(2): 130-134, 2010.

[23]. Loeken M.L., A New Role for Pancreatic Insulin in the Male Reproductive Axis, Diabetes, 61(7): 1667-1668, 2012.

[24]. Dam A.H., Ramos 1., Dijkman H.B., Woestenek R., Robben H. Van Den Hoven L., and Kremer J.A., Morphology of Partial GlobozoospermiaJournal of Andrology, Vol. 32, No. 2, 2011.

[25]. Brahem s., Mehdi M., Elghezal H., and Saad A. The effects of male aging on semen quality, sperm DNA fragmentation and chromosomal abnormalities in an infertile population, J Assist Reprod Genet., 28(5): 425-432,2012. 
[26]. Baccetti B., Marca A.L., Piomboni P., Capitani S., Bruni E., F., And Leo V.D., Insulin-dependent diabetes in men is associated with hypothalamo-pituitary derangement and with impairment in semen quality, Human Reproduction Vol.17, No.10 pp. 2673-2677, 2002 .

[27]. Silvestroni L, Modesti A, Sartori C, Insulin-sperm interaction: effects on plasma membrane and binding to acrosome, Arch Androl. 28(3):201-11., 1992.

[28]. Bansal A.K., Manganese: A Potent Antioxidant in Semen, Iranian Journal of Applied Animal Science, 3(2), $217-22,2013$.

[29]. Franca L.R, Ogawa T., Avarbock M.R., Avarbock M.R, Brinster R.L, Russell L.D. Germ cell genotype controls cell cycle during spermatogenesis in the rat. Biol. Reprod.59:1371-7.,1998. 